\title{
Can All Voices Be Heard? Active Learning Strategies Enhance FSL Oral Production
}

\author{
Sophia Bello \\ University of Toronto \\ Canada
}

\begin{abstract}
Learning is not a spectator sport. Students do not learn much just by sitting in classes listening to teachers, memorizing pre-packaged assignments, and spitting out answers. They must talk about what they are learning, write about it, relate it to past experiences and apply it to their daily lives. They must make what they learn part of themselves. [...] Students need the opportunity to show their talents and learn in ways that work for them. Then they can be pushed to learning in new ways that do not come so easily.
\end{abstract} (Chickering and Gamson 4, 6)

\section{Introduction}

As instructors of French as a Second Language (FSL), one of our present concerns is the lack of adequate knowledge about which activities can enhance students' oral production. In a traditional passive learning environment, the instructor takes charge of the classroom, presents lectures, and is the only one to assess students' progress (Michel et al. 59). Students often respond with minimal interest and complain anonymously in their evaluations that there is insufficient time allocated for oral practice and minimal feedback provided by the instructor's assessment of their work. Active or experiential learning, on the other hand, provides opportunities for learners to take charge of the classroom and express themselves. Active learning strategies are an integral part of language courses because active participation encourages students to become more involved in the learning process (Kohonen). As Cross wrote, "When students are actively involved in the learning task, they learn more than when they are passive recipients of instruction" (3). As language instructors, we should design a course that bears in mind the learner's perspective and provide enough guidance for students to move forward rather than backward. When a student is a participant, rather than a spectator, he/she steps up and takes control of the given situation.

In this paper, we argue that an active learning approach, rather than a passive one, provides an optimal environment for all types of learners. Through student-run workshops in a post-secondary advanced FSL course, students assume some responsibility for their own language learning experience. These workshops encourage discipline, teamwork, motivation and leadership, among other skills. ${ }^{1}$ Furthermore, the instructor becomes the learner and can also use this time to observe how students react to different learning stimuli, how their levels of engagement change depending on the type of activity, and can assess their oral progress. Additionally, supporting and encouraging students to share their experiences and viewpoints can lead to teaching and learning rewards for instructors and students.

In what follows, three types of activities will be presented as highly effective methods to engage learners in a second language course:

1. An online-based activity: KAHOOT!

2. A discussion-based activity: a debate on parental leave benefits in Canada and France

3. A team-building activity: story-telling through imagery

These methods have many advantages. They play a significant role in fostering the needs of our students and offering a space where learning can be enjoyed. In fact, the different activities proposed by the students during the workshops led to greater overall participation compared to the lecture portion of the course. Like all learning methods, challenges that surface and need to be further explored will be addressed.

\section{Active Learning Strategies in Post-Secondary Level Education}

Active learning drives students to take on an active role in the classroom and to participate, collaborate, and engage personally, with their instructor and peers, as well as with the content of the course. Many research 
studies demonstrate the following advantages that come from using active learning strategies in post-secondary education (Bonwell and Eison; Felder and Brent):

1. Increases motivation, participation and creativity

2. Appeals to different levels of proficiency

3. Offers a relaxing and cooperative environment

4. Enables work in a small group setting

5. Encourages students to become the teacher

6. Covers different learning styles and language competencies

These advantages, among many others, encourage instructors to reconsider how to guide students towards increased oral production in the classroom. Teachers should determine how the material can best be presented to promote student engagement throughout a semester. The motivation behind this method of learning is to overcome the challenges instructors face, especially when teaching a large group of students (approximately 40 in FSL405) how to start and maintain a conversation on any topic presented. First, there were some unrealistic expectations by the students. Through a classroom survey initiated in the first week of class in September, students were asked the following question: Which proficiency level (oral production) would you like to reach by the end of the semester? As indicated in the following table, what some students expected to achieve by the end of a 12-week course was beyond the time and energy they would invest into the course.

\begin{tabular}{|l|l|l|}
\hline Student & Languages Acquired & $\begin{array}{l}\text { Speaking Skills and Expectations for French Oral } \\
\text { Production }\end{array}$ \\
\hline 1 & English > Yoruba > French & $\begin{array}{l}\text { I have a lot of difficulty speaking in French and would like } \\
\text { to become an expert speaker by December. }\end{array}$ \\
\hline 8 & English > French > Portuguese & $\begin{array}{l}\text { I can communicate in French, but formulate my sentences } \\
\text { very slowly. I would like to be fluent by the end of the } \\
\text { semester and considered and advanced speaker. }\end{array}$ \\
\hline 18 & English > Urdu > French & $\begin{array}{l}\text { I do not get a lot of opportunities to speak French. When I } \\
\text { do, it takes a long time to construct my sentences. My } \\
\text { goal is to become fluent in this course. }\end{array}$ \\
\hline 21 & Spanish > English > French & $\begin{array}{l}\text { My oral proficiency is between a beginner and } \\
\text { intermediate level. My goal is to be an advanced speaker } \\
\text { who can communicate with anyone in a francophone } \\
\text { country and land a job in French. }\end{array}$ \\
\hline
\end{tabular}

Following the first intermediate level (B1.1) course, students in FSL405 continue to develop oral skills in the production of complex discourse (including organization, cohesion, nuanced lexical forms and expressions) to participate in varied, sustained and unscripted situations. The course objective was to communicate through small group activities using the essential constructions of French grammar, including syntax and an extensive use of vocabulary. Their responses contrast with the learning outcomes of the course. Therefore, it was essential to find a way to encourage them and make them feel they could progress in smaller and more realistic steps towards achievement of the learning objectives of the course. The second challenge was to find a way to promote and increase students' active participation as well as to appeal to their interests and needs. In a large tutorial class, only a small number of students were motivated and took charge of their own learning. Most students often sat back until called upon. It became the teacher's mission to drive each individual learner to participate. To resolve this issue, students were given the opportunity to take turns practicing their French conversational skills in smaller groups. This way, they could encourage each other to overcome their fears and surpass their limits. Once students were given the necessary guidelines to follow, the third and final challenge was to decide which activities best fit their needs. Since their active involvement and role had to be emphasized, students were required to come up with a workshop that was instructive, creative, and included everyone. The learning process depended on them and how far they were willing to go to put their teaching skills into practice.

The activities we will discuss shortly were created and administered by the students during weekly student-run reading workshops. 


\section{FSL405: Student-Run Reading Workshops}

Entitled Functional French-Advanced I, FSL405 is a course designed to help Intermediate French Level students who have prior knowledge of the language, but require further improvement of their listening, speaking, reading and writing skills in French. Two hours of the course were dedicated to grammar, vocabulary learning, reading, writing, listening tasks and exercises. Each grammar lecture facilitated students' abilities in other related domains of language learning and allowed the instructor to assess their French proficiency skills. On a separate day, a tutorial hour was devoted to the student-run workshops. To guide the students in the right direction, the first tutorial session was a teacher-run workshop on traveling and building a travel blog. It was important to demonstrate how to develop and run a workshop, especially when most students were unfamiliar with the concept.

The following guidelines were provided:

\section{Goal}

Consider the theme of the week and lead an active discussion with various activities that encourage student participation.

\section{Guidelines for an Effective Workshop}

1. Introduction: introduce each other and the objectives of your presentation.

2. Discussion: using the questions provided by other groups, elaborate on the theme of the reading and the lesson of the week.

3. Activity: create at least one activity that includes all members of the class.

4. Conclusion: explain the reasons behind your workshop's organization and the lessons learned.

\section{Time Management Tips and Work Ethics}

Manage your time wisely: 30 minutes for the lecture/discussion/activity and a 5-minute closing.

Ensure that each member of the group participates equally.

Each activity must be creative and unique to the weekly theme/reading.

Provide a copy of the activities and PowerPoint presentation to the instructor.

Each week, students worked in small groups to design reading workshops and present work using oral, written and audio-visual activities. This offered them a chance to lead the class while the instructor mediated and evaluated their work. Using this type of approach with undergraduate students instils self-confidence and increases motivation and control over one's own learning (Paxman et al.). In FSL405, it allowed advanced French speakers to reflect on their own experiences and the endless possibilities of future career paths (e.g., teaching, public speaking, networking, etc.). Furthermore, active learning strategies are meant to promote individuality, group work and fairness in the classroom (Bonwell and Eison). The more involved a learner becomes, the more likely they are to include themselves and their interests in classroom discussions and activities throughout the semester (Cross; Michel et al.; Schor et al.).

To maintain consistency in the course, most of the readings were assigned from Girardet and Pêcheur's textbook entitled Echo B1.2. In small groups of three to five, students chose their own group name and were randomly assigned a date to run their workshop. The weekly readings were available a week prior to each workshop to ensure that each group had sufficient time to prepare and contact the instructor if assistance was required. 


\begin{tabular}{|l|l|l|}
\hline Group name & Reading & Weekly Theme \\
\hline 1. Maestros & Le Festival Interceltique de Lorient & $\begin{array}{l}\text { Traditions \& multicultural } \\
\text { activities }\end{array}$ \\
\hline 2. Incroyables & Notre réglementation est-elle appropriée? & Driving rules \& obligations \\
\hline 3. Pamplemousses & Les médias nous disent-ils la vérité? & Media truths \& information \\
\hline 4. Génies & Concilier vie de famille et travail & Careers \& professionalism \\
\hline 5. Citrouilles & Grand nettoyage de fin d'année & $\begin{array}{l}\text { Work/life balance \& } \\
\text { organisation }\end{array}$ \\
\hline 6. Formidables & Un mode d'apprentissage efficace & Learning through games \\
\hline 7. Fantastiques & Un texte portant sur les développements au & Economical growth \\
\hline 8. C'est la vie! & A faire...une fois dans sa vie & Passions \& interests \\
\hline
\end{tabular}

Sessions were approximately 30 to 40 minutes long depending on the number of students in a group. To make sure that everyone participated and showed up to the workshops, Lyman's think-pair-share technique was implemented. First, each student had to do the weekly reading and think about how it related to the theme of the week. Then, each paired group had to share their ideas and come up with one question that would be posted on an online discussion board. Finally, during the student-run workshop, the facilitating group would consider the questions and share their thoughts and responses with the entire class. This way, every group could be assessed for their participation. At the end of each workshop, students summarized the lesson and the entire class could provide some feedback or ask last minute questions on the theme, presentation, or activities.

The main purpose of these small group workshops was to encourage students to be creative as individuals as well as members of a group. They showed great interest in cooperating and sharing their ideas when given the freedom to do so. This method proved useful in assessing French oral skills at both group and individual levels. While student-run workshops are often challenging and require that the teacher relinquishes some control, they can also be extremely beneficial to the learners and far more exciting than the lecture component of the course. The instructor's role during the workshops was to remain out of sight to evaluate the work being presented. The following Evaluation Grid enabled the instructor to assess each individual student (80\%) and their work as a group (20\%). The percentage assigned specifically to the group was high enough to encourage quality collaboration. 
\begin{tabular}{|lr|}
\hline Grille d'évaluation (Evaluation Grid) & \\
Contenu (Content) 40\% & $/ 10$ \\
Profondeur des idées (Depth of ldeas) & $/ 20$ \\
Qualité de l'analyse (Quality of the Analysis) & $/ 10$ \\
Originalité (Originality) & \\
& $/ 10$ \\
Expression orale (Oral Expression) 40\% & $/ 10$ \\
Prononciation et articulation (Pronunciation and Articulation) & $/ 10$ \\
Grammaire (Grammar) & 110 \\
Vocabulaire (Vocabulary) & \\
Aisance (Ease) & $/ 5$ \\
& $/ 5$ \\
Groupe style de présentation (Group Presentation Style) 20\% & $/ 10$ \\
Organisation (Organization) & \\
Créativité (Creativity) & $\mathbf{1 0 0}$ \\
Discussion (Discussion) & \\
&
\end{tabular}

The involvement and participation of the instructor was at the sole discretion of the students. They had to manage a classroom, think outside the box, and come up with a presentation that included informal conversational activities. It was up to them to engage their classmates and provide a workshop that could last the entire session.

This created a learning environment where students were attentive because they were captivated by each activity and enjoyed communicating with each other without worrying about their language skills. Some of the most memorable student-run activities included teaching the Scottish dance steps for the Lorient Interceltic Festival and using talking circles to discuss minimalism and uncluttering tips. The most amusing game incorporated the Jelly Belly BeanBoozled Jelly Bean Game with a timer. Before the time was up, each student had to name an interest or describe something they were passionate about and wanted to fulfill before they die.

In this course, three types of activities stood out among the rest: (i) an online questionnaire using Kahoot! ("Making Learning Awesome"), (ii) a lively debate on parental leave, and (iii) using images to develop a unique story. We will explore the pros and cons for each activity and highlight a way to improve their use in an FSL course.

\section{Activity 1: Online-based - Kahoot!}

Kahoot! is a game-based classroom response system co-founded by Johan Brand and Jamie Brooker in Norway. According to Brand, "Play is our first language and shared by all humans. Therefore, it's the foundation of our approach to an inclusive \& student-centred classroom. Inclusive design for us is both about the interaction design and the behaviours it instigates" (qtd. in "Inclusive Design"). This tool has been used across elementary and secondary levels of education and has made its way into undergraduate classrooms. Using a multiple-choice platform, it initiates peer-led discussions and engages everyone in real time.

One group decided to test this activity at the beginning of their workshop. The goal was to start with a fun warmup exercise, then check if everyone had done the reading and could recall key vocabulary terms. The group prepared a series of questions taken from the weekly reading. They instructed their classmates to log in using either a cell phone, laptop, or tablet. Each question was then projected on the screen with 15 seconds to tap one's choice. Once time had elapsed, the correct answer appeared with a leaderboard. The entire process took about five minutes followed by a post-game discussion session. This activity encouraged competition, awareness, and memory assessment. Kahoot! appealed to the students because it was animated, easy to use with a colorful layout and cheerful sounds. 
From a teacher's point of view, it is a great way to welcome the students into a workshop. It is easily adaptable for different levels of language proficiency, stimulates post-discussion, and most importantly, keeps the students engaged throughout the session. On the other hand, the students did not maximize the potential of Kahoot! as a learning tool and could have done more than simply asking students to quickly choose their answer. As an alternative, a time interval could be planned between each question to allow students to discuss the four options and debate which answer is the correct one. If students are required to work in small groups, rather than individually, then the use of one device per group would create further teamwork and encourage all students to participate. This type of group engagement would also include any students who do not own or bring a personal device to class.

\section{Activity 2: Discussion-based - Debate on Parental Leave Benefits}

Conducting debates in a second language course can have a positive impact on student learning and in teaching critical thinking. According to Rear, this method is effective because it is "encouraging an active and careful approach to an issue; generating a questioning attitude toward knowledge and beliefs; and stimulating learners towards a critical view of the world around them" (56). While learners require guidance in executing a successful debate, this form of activity does animate the class and can even stimulate the quietest students.

One group found that a formal discussion on the topic of parental leave was the best way to engage their classmates. The weekly reading presented a comparative analysis on parental leave benefits in Canada and in France. The goal was to determine how students would react and defend their side if given one of two choices: to support or refute the benefits. Each group used the data and information provided to reinforce their ideas on the topic. The class was divided into two and given ten minutes to review their assigned reading and prepare their defense. Each side took turns presenting their arguments which had to be counteracted by the other team. The facilitating group tallied up the points for each argument and chose which side best executed their defense. In the end, the group who supported the benefits won. Everyone was so focused on the preparation and debate that the instructor became invisible during the discussion. It was an extremely proud moment where the roles were completely reversed.

This activity encouraged teamwork, discipline, and proper linguistic performance. If the right topic presents itself, the discussion can be ongoing and requires little effort on those leading the workshop. Regardless of one's beliefs, each student must be able to defend the notions set forth without letting their own emotions get in the way. A debate is a great discussion-based activity that initiates a series of questions centered around cultural differences and preliminary notions on a topic. Although it works best with intermediate and advanced learners, it can also be integrated into beginner classes with simpler guidelines and shorter discussions. Unlike Kahoot!, it is not meant to be an entertaining activity that lasts for a few minutes. Instead, it is a stimulating activity that incorporates oral practice and pushes the boundaries of critical thinking. The downside is that students may not have enough time to analyze the information thoroughly. Many learners are unable to create a profound discussion given the limitations of their language proficiency. One possibility to overcome this obstacle would be to give students time to prepare their arguments during the week leading up to the debate. This way, those who struggle to put together their thoughts are given ample time to do so and those who are successful in establishing their viewpoints can lead their group into a lively debate.

\section{Activity 3: Team-building - Story-Telling Through Imagery}

The third and final group activity we will discuss was based on the theme of economic growth and the group leading the activity determined that team-building exercises would be appropriate. Team-building activities have been used in various employment sectors as "a way to provide high-impact learning, increase team skills and communications, and improve morale and productivity” (Magloff).

Since the end of the semester was fast approaching, the facilitating group felt it was important that the entire class continue to work together and take what they had learned into the second half of the course, offered in the following semester. Therefore, the class was broken into two groups and shown a series of images projected on the screen. Images included animated figures like Shrek, transportation vehicles, natural landscapes, and others. Each group had a few minutes to choose three images and develop a story on economic growth. Every student had a role to play, whether it was writing down the story, developing it, or describing it to the class. The facilitating group served as a panel of judges to determine which team presented the best story. 
Student participation, especially for those who shy away from oral production, was exceptional. The stories they developed were highly imaginative and connected to the topic at hand. This activity brought on lots of laughter, puzzling looks, and some last-minute improvisation. As the instructor, it was surprising to find that this topic could be presented in such an entertaining and captivating manner. The main recommendation made by the students following the workshop was whether they could have been separated into even smaller groups to present more stories. If planned accordingly, team-building activities can motivate students to dig deep into their creative side, and ultimately, overcome their fear of speech.

\section{Next Steps}

Students' participation increased tremendously week after week, especially when activities were fun, animated, and unconventional. Some groups put considerable effort into designing engaging games and well-planned activities. Others struggled and required a push to complete their workshops, often choosing a more traditional way of teaching a topic. Without sufficient experience and interest, it can be a challenging and stressful journey when the students are asked to take on the role of instructor. In terms of evaluation, group and individual work were assessed by the instructor. Future FSL student-run workshops could benefit from requiring students to reflect on their presentation and complete a self-assessment. The instructor could also introduce a peer assessment component, asking for voluntary and anonymous weekly feedback.

By implementing active learning strategies in the classroom, students were encouraged to take charge of their own education. Whether this is the right direction for future FSL courses remains to be seen. For now, we can consider what has worked and reflect on the suggestions provided by the students in their course evaluations. First, each facilitating group hoped that the instructor would provide the questions to be discussed during the workshop. While the instructor should aim to remain on the sidelines, there is still a need for his or her presence and participation, even if minimal. Additionally, students requested to present two workshops a semester and to receive more feedback. Although this would add to the workload of the instructor, it demonstrates students' eagerness to succeed and improve their language skills. Finally, students would have preferred having the option to choose their own reading. This can easily be accommodated if the textbook allows the instructor to do so or if alternate sources are identified.

The observations made during the student-run workshops reveal that using active learning strategies improves oral production. Moving forward, it would be most valuable to obtain student feedback and see whether they personally observe how these strategies lead to better oral production. Further studies can be planned to reproduce the methodology in additional FSL classes. Students could be provided with more detailed guidelines and better steps and directions to take when developing a workshop. A list of activities such as the ones presented in this paper could be pre-determined by the instructors and applied at every level. This would allow students to learn the activities and choose which ones to include in their workshop. Since many language courses are taught by different instructors year after year, instructors could reduce the workload and collaborate by proposing a few activities and sharing active learning strategies that have worked in preceding years.

To conclude, students in FSL405 have greatly benefited from running their own workshops under proper guidance and encouragement. By creating an open environment for learning, they further developed the skills and the confidence required to maintain a conversation in French with their peers. By beginning the discussion on the effects of active learning in post-secondary education, we are one step closer to facilitating students' language learning.

\section{Note}

${ }^{1}$ Schor et al. demonstrate several benefits associated with including student-run workshops in the Department of Electrical and Computer Engineering at the University of Manitoba. This demonstrates the extent to which workshops can be used across departments and programs to enhance student experience and active involvement in the classroom. 


\section{Works Cited}

Bonwell, Charles C. and James A. Eison. Active Learning Creating Excitement in the Classroom (ASHE-ERIC Higher Education Rep. No. 1). George Washington University, 1991.

Chickering, Arthur W. and Zelda F. Gamson. "Seven Principles for Good Practice in Undergraduate Education." American Association of Higher Education Bulletin, vol. 39, no. 7, 1987, pp. 3-7.

Cross, Patricia. "Teaching for Learning." American Association of Higher Education Bulletin, vol. 39, no. 8, 1987, pp. 3-7.

Felder, Richard M. and Rebecca Brent. "Active Learning: An Introduction." ASQ Higher Education Brief, vol. 2, no. 4, 2009, pp. 1-5.

Girardet, Jacky and Jacques Pêcheur. Echo B1.2 - 2e Ed.: Méthode de Français. 2e ed., CLE International, 2013.

"Inclusive Design." ICT-Kahoot!, Design and Architecture Norway, 2010, www.inclusivedesign.no/ict/kahoot-article172-261.html?redirect=invalidurl.

Kohonen, Viljo. "Learning to Learn Through Reflection - An Experiential Learning Perspective." Preparing Teachers to Use the European Language Portfolio - Arguments, Materials and Resources, Council of Europe Publishing, 2007.

Lyman, Frank. "The Responsive Classroom Discussion: The Inclusion of All Students." Mainstreaming Digest, edited by Audrey S. Anderson, University of Maryland Press, 1981, pp. 109-113.

Magloff, Lisa. "The Benefits of Team Building." Demand Media, Hearst Newspapers, 2016, smallbusiness.chron.com/benefits-team-building-1979.html.

"Making Learning Awesome!" Kahoot!, Kahoot! AS, 3 Sept. 2013, getkahoot.com.

Michel, Norbert, et al. "Active Versus Passive Teaching Styles: An Empirical Study of Student Learning Outcomes." Small Business Institute National Proceedings, vol. 33, no. 1, 2009, pp. 55-.67.

Paxman, Jenny R., et al. "Motivation, Confidence, and Control; Unraveling Active Learning for Nutrition and Food Undergraduates." Journal of Food Science Education, vol. 10, 2011, pp. 45-53.

Rear, David. "Critical Thinking, Language and Problem-Solving: Scaffolding Thinking Skills through Debate." Essential Competencies for English-medium University Teaching, edited by Ruth Breeze and Carmen Sancho Guinda, Springer International Publishing, 2017, pp. 51-63.

Schor, Dario, et al. "Complementing Classroom Experience with Student-Run Workshops." Proceedings of the Canadian Engineering Education Association, CEEA/ACEG, 2012. 